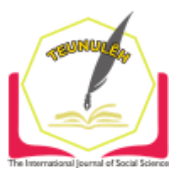

Jurnal Ilmiah Teunuleh

The International Journal of Social Sciences

Vol. 1, Issue. 2, Dec 2020

E-ISSN: 2746-4393

\title{
TEACHING STRATEGIES: EFL STUDENTS' RESPONSES TOWARD TEACHER STRATEGIES IN READING COMPREHENSION
}

\author{
Sri Wahyuni ${ }^{1}$ \\ Rosdiana ${ }^{2}$ \\ Hanifar Mardhatillah ${ }^{3}$ \\ STKIP Bina Bangsa Getsmpena \\ ${ }^{1}$ sri@bbg.ac.id, ${ }^{2}$ rosdiana@bbg.ac.id, ${ }^{3}$ hanifarmardhatillah87@gmail.com
}

\begin{abstract}
The purpose of this study is to find out the teacher strategies in teaching reading comprehension at the first-grade students at SMA Inshafuddin Banda Aceh. This research employed a descriptive qualitative method. The participants of this research is the first grade students of SMA Inshafuddin Banda Aceh that consist of 30 students. The instruments of collecting the data used in this study is a questionnaire. The objectives of this research were to know the students' responses of the teacher strategies in teaching reading comprehension. In this research, the result revealed that that the students' responses toward the teacher strategies in teaching reading comprehension it showed positive responses.
\end{abstract}

Keywords: Teacher Strategies, Reading Comprehension

\section{A. Introduction}

Reading is one thing that is very necessary in getting knowledge (Christina, 2019). Thus, reading is very influential skill for EFL students, by reading they can get more information sharing from the author ideas. Therefore, reading is a process of understanding the meaning of a text in which the readers can know an important idea and an information of what they have read. By reading many books we can know anything that we do not know before, reading some information can give as reference to write. Hence, when reading students need to have large vocabulary and master grammatical rules to understand what the text is talking about. It can conclude that reading in foreign language is a process that must be learned by the student. As the 
result, reading is the skill in order to help the student successful during teaching learning in the school.

Furthermore, Tarigan (2011) state that reading is one of the four language skills made and used by the reader to find the message to be delivered by the author through words.It is means that reading is process for get information in a text to read and then by reading also students can understand the writer means and also to make it succesfully we have to know what the words means. that means reading is an important activity in reading a text. we as the readers must need to know what we read, and what the word mean, that way it cause the readers clear to get main ideas from the text and the reading activity will gain the purpose.

In addition, Mickulecky (2007) state that reading comprehension is about an understanding what you have read not just knowing the words, but it may connected between ideas that stated in the text, and reading comprehension can also be interpreted as thinking while reading what has been read before. Besides, reading refers to comprehen the text at the process of understanding written text. It is related to what they do not know about information to they have already known. Reading really depends on some information through the eyes to the brain.

Reading comprehension is the ability to read a text and it need a process and understand the authors' ideas. An individual's ability to comprehend the reading text was influenced by their traits and skills. As stated by Meliyawati (2016), reading is a process and the skills in order to be able to understand a reading text that is being read by the reader and as a part of a complex activity process that must be done by the reader. Because it involves some elements in the reading text when the reader needs to understand the contents of the reading itself.

Hurwitz in Nisa, et al (2018) define that reading is a way and as a process to search meaning or information from written material. In other words by reading students get information from written letters and words that create the student more successful in skill reading. In addition, reading skills are more focused on the ability to improve reading comprehension because the ability to understand reading text is the main goal to be achieved in teaching and learning reading effectively.

In the classroom, teaching reading is a way of transferring knowledge from teacher to students by using a certain technique of strategy and a certain material in order to master reading itself. Teaching is a complex process that is not only give the information from the teacher to the students but it also the students process of getting a knowledge. 
Teaching Strategies: EFL Student's Responses Toward Teachers Strategies...

As supported by Buchari (2009) that teaching and learning is a skill in itself can be studied as a science as well as art. Therefore, reading it self is one of the ways to make the students understanding the transferring knowledge in teaching learning process.

In addition, Suyanto (2013:2) says that the essence of teaching is a process that leads students to learn. Besides, teaching activities include material preparation, concluding and discussing material, providing facilities, solving problems in the learning process, guiding all students, and also providing motivation. Thus, will help the students more enthusiasm in learning. Meanwhile, when the teacher teaches, there must be a problematic in teaching learning process, because some students can face a difficulty and stressful at times, but it is also worth to remember that at its best teaching can also be extremely enjoyable. Based on explanation, the writer concludes that teaching activities and manages the environment in a good condition to make and give the opportunity for the students in learning process to get the purpose.

Furthermore, learning process is implemented using a specific strategy, the strategy that the teacher use can influence the success of the learning process. According to Muslaini (2017:67), learning strategy ca be defined as a general direction set for the teaching process. Therefore, learning strategies are action plans or series of activities including the use of methods, learning media and the use of various sources in learning process. Choosing the right strategy can create students more active and fun in the classroom when the teacher teachs the subjects. It means, strategies are arranged to achieve a certain goal, and make the students can easily receive learning materials properly.

\section{B. Method}

The design of this research is descriptive qualitative, as stated by Margono (2010:8), descriptive method is a method that seeks to provide a systematic and careful with the actual facts and nature of certain populations which aims to solve the current problems and collect the data or information to be arranged, described, and analyzed. This kind of analysis is done with the help of words to describe any detailed conclusion or interpretation in a less biased and to get the systematic data.

The purpose of this research is to know the teacher strategies in teaching reading comprehension and the student's responses of the teacher strategies in teaching reading comprehension class of the students at SMAS Inshafuddin Banda Aceh. Researcher used this sampling because selecting samples by using purposive sampling is not all samples 
have criteria that match the researcher determine. The researcher decided to conduct the research to the first-grade students in SMAS Inshafuddin Banda Aceh. Thus, the researcher gave the questionnaire to the students as the research instrument. The questionnaires that is used in this research is closed questionnaires. So that, the students provide their opinion to the questions with choosing the available answer. The questions in the questionnaire are about the students' responses toward the teacher strategies in teaching reading comprehension.

This questionnaires provided 13 questions that the students need to answer. This questionnaire is objectively to get any information about the students responses of the teacher strategies in teaching reading comprehension.

\section{Finding and Discussion}

This research aimed to describe the teacher's strategies in teaching reading comprehension. This section presents and discusses the research finding of this research based on the data obtained from the first-grade students of SMA Inshafuddin Banda Aceh.

\section{Finding}

In this research finding, the researcher described all the finding of the research that has been discovered for the teacher's strategies in teaching reading. The list of questionnaire consists of thirteen questions that have different statement from the question and its findings as follow.

Table 1. Students' Questionnaire Result for Number One

\begin{tabular}{lcccc}
\hline \multicolumn{2}{c}{ Statement of questions } & Students Answer & Frequency & Percentage \\
\hline Does the English teacher & Yes & 22 & $73.3 \%$ \\
monitoring & reading & No & - & 0 \\
comprehension of students & Sometime & 2 & $6.7 \%$ \\
while the students do not & Often & 6 & $20 \%$ \\
understand about reading & & & \\
text? & & & \\
\hline
\end{tabular}

From the table above, $73.3 \%$ of the 30 students respond ' $y e s$ ', the English teacher monitoring reading comprehension of students while the students do not understand about reading text. None of the students answered that the English teacher does not monitoring the reading comprehension while teaching and learning activities. Then, $6.7 \%$ of the students who answered that sometimes the teacher monitoring reading 
Teaching Strategies: EFL Student's Responses Toward Teachers Strategies...

comprehension of students. Besides, there are $20 \%$ of the students stated that English teacher monitoring the reading comprehension while the students do not understand the reading text. It can conclude that percentage of students who gave positive response about that question was higher than negative response.

Table 2. Students' Questionnaire Result for Number Two

\begin{tabular}{lccc}
\hline \multicolumn{1}{c}{ Statement of questions } & Students Answer & Frequency & Percentage \\
\hline Does the English teacher ask & Yes & 23 & $76.7 \%$ \\
the students to identify the & No & 1 & $3.3 \%$ \\
structure of the story in the & Sometime & 1 & $3.3 \%$ \\
reading text? & Often & 5 & $16.7 \%$
\end{tabular}

As the finding of the table above, it can be seen that $76.7 \%$ of $100 \%$ of students answered yes that the teacher asked to the students to identify the structure of the story in the reading text. Then, $16.7 \%$ the students said that teacher often asked to the students to identify the structure of the story in the reading text. Next, the percentage of the table above it showed that the 3.3\% answered sometime if the students asked to identify the structure of the story in the reading text. Also, 3,3\% students said no about this question. It proved that percentage that the teacher mostly asked to the students to identify the structure of the text.

Table 3. Students' Questionnaire Result for Number Three

\begin{tabular}{|c|c|c|c|}
\hline Statement of questions & Students Answer & Frequency & Percentage \\
\hline Does the English teacher ask & Yes & 23 & 76.7 \\
\hline the students to answer & No & 2 & $6, .7$ \\
\hline questions based on & Sometime & 3 & 10 \\
\hline $\begin{array}{l}\text { information that the } \\
\text { students get from the } \\
\text { reading text? }\end{array}$ & Often & 2 & 6.7 \\
\hline
\end{tabular}

Based on the table above, it showed that $76.7 \%$ of $100 \%$ of students answered yes that the teacher asked to the students to answered the questions based on the information that they got from the reading text. Beside, the students said sometime about $10 \%$ of the students said that the teacher sometime asked the students to answered question based on information that related to the reading text. Then the students said no and often have the same percentage, there is only $6.7 \%$ of the students answered no. Even though, there is only 6.7\% answered often. It proved that percentage of students who gave positive response about that question was higher than negative response. 
Sri Wahyuni, Rosdiana, Hanifar Mardhatillah

Table 4. Students' Questionnaire Result for Number Four

\begin{tabular}{lccc}
\hline \multicolumn{1}{c}{ Statement of questions } & Students Answer & Frequency & Percentage \\
\hline Does the English teacher ask & Yes & 15 & 50 \\
the students to make some & No & 7 & 23.3 \\
questions and answer the & Sometime & 7 & 23.3 \\
questions based on reading & Often & 1 & 3.3 \\
text? & & & \\
\hline
\end{tabular}

The finding for the fourth questionnaire, $50 \%$ of $100 \%$ of students answered yes that the teacher asked to make some questions and answered the question based on reading text. However, $23.3 \%$ of the students answered no and sometimes. It was the same percentage that the students answered in the questionnaire that the teacher does not asked the students to make some questions and answered the question based on reading text. Even there is some students said no, but there are some students answered the teacher sometimes asked the students to make questions and answered. There is 3.3\% mentioned that teacher often asked the students to make some question and answered the question in reading text.

Table 5. Students' Questionnaire Result for Number Five

\begin{tabular}{|c|c|c|c|}
\hline Statement of questions & Students Answer & Frequency & Percentage \\
\hline Does the English teacher ask & Yes & 15 & 50 \\
\hline the students to write the & No & 8 & 26,7 \\
\hline important concept in the & Sometime & 4 & 13,3 \\
\hline reading text? & Often & 3 & 10 \\
\hline
\end{tabular}

Based on the table above, the fifth question could be conclude that $50 \%$ of students answered yes that the teacher asked the students to wrote the important concept in the reading text. $26.7 \%$ answered No the teacher asked the students to wrote the important concept in the reading text. However $13.3 \%$ mentioned asked the students to wrote the important concept in the reading text. Beside there is only $10 \%$ of the students answered the teacher often asked the students to write the important concept in the reading text.

Table 6. Students' Questionnaire Result for number six

\begin{tabular}{lccc}
\hline \multicolumn{1}{c}{ Statement of questions } & Students Answer & Frequency & Percentage \\
\hline Does the English teacher ask & Yes & 8 & 26,7 \\
the students to summarize & No & 8 & 26,7 \\
the text by using the original & Sometime & 13 & 43,3 \\
word by the students? & Often & 1 & 3,3 \\
\hline
\end{tabular}


Teaching Strategies: EFL Student's Responses Toward Teachers Strategies...

The sixth questionnaire resulted the high percentage that the teacher sometimes asked the students to summarize the text by used their original words. It was $43.3 \%$ of the students answered sometimes in this question. There is $26.7 \%$ of the students showed that the same result for yes and no that answered by the students. However, only 3.3\% of the students answered often about this question. It means it was the lowest percentage of this question section.

Table 7. Students' Questionnaire Result for Number Seven

\begin{tabular}{|c|c|c|c|}
\hline Statement of questions & Students Answer & Frequency & Percentage \\
\hline Does the English teacher & Yes & 15 & 50 \\
\hline ask the students to & No & 5 & 16,7 \\
\hline remember and memorize & Sometime & 6 & 20 \\
\hline $\begin{array}{l}\text { vocabulary that the } \\
\text { students read in reading } \\
\text { text? }\end{array}$ & Often & 4 & 13,3 \\
\hline
\end{tabular}

The data in the table above showed that $50 \%$ of the students stated yes, about the teacher asked the students to remember and memorize vocabulary in reading text. On the other hand, $20 \%$ of students answered the teacher sometime asked the students to remember and memorize vocabulary. Beside $16.7 \%$ of the students said no for this question and $13.3 \%$ students choice often in this statement. From the result above we can saw different percentage for each students answered.

Table 8. Students' Questionnaire Result Number 8

\begin{tabular}{|c|c|c|c|}
\hline Statement of questions & Students Answer & Frequency & Percentage \\
\hline Does the English teacher & Yes & 15 & 50 \\
\hline when the students get & No & 3 & 10 \\
\hline bored in teaching learning & Sometime & 8 & 26,7 \\
\hline $\begin{array}{l}\text { process, the English } \\
\text { teachers give the students } \\
\text { game and motivated the } \\
\text { students? }\end{array}$ & Often & 4 & 13,3 \\
\hline
\end{tabular}

From the result above, it can be seen that $50 \%$ of students answered yes that the teacher gave game and motivation when the students get bored. Then, $26.7 \%$ the students said that the teacher sometime gave game and motivation to the students when the students get bored. There are $13.3 \%$ students said often and $10 \%$ students answered No that the teacher when the students get bored, the teacher gave game and motivation to students in teaching learning process. 
Sri Wahyuni, Rosdiana, Hanifar Mardhatillah

Table 9. Students' Questionnaire Result for Number Nine

\begin{tabular}{lccc}
\hline \multicolumn{1}{c}{ Statement of questions } & Students Answer & Frequency & Percentage \\
\hline Does the English teacher & Yes & 16 & 53,3 \\
ask the students to point & No & 2 & 6,7 \\
out the main idea of the & Sometime & 11 & 36,7 \\
text that has been read by & Often & 1 & 3,3 \\
the students? & & & \\
\hline
\end{tabular}

The finding of the ninth questionnaire showed that $53.3 \%$ of students answered yes on the statement that the teacher asked to the students to point out the main idea of reading text. Beside, $36.7 \%$ the students said that teacher sometime asked to the students to point out the main idea of reading text. On the other hand, $6.7 \%$ of the students answered no. Similarly, only one student that answered often in this question. It showed by the table that only 3.3\% of the students answered it.

Table 10. Students' Questionnaire Result for Number Ten

\begin{tabular}{lccc}
\hline \multicolumn{1}{c}{ Statement of questions } & Students Answer & Frequency & Percentage \\
\hline Does the English teacher & Yes & 26 & 86.7 \\
give the reading material & No & 2 & 6.7 \\
based on the ability of the & Sometime & 0 & 0 \\
students? & Often & 2 & 6.7 \\
\hline
\end{tabular}

The data on the table above, it found that a positive responses of the students because it was the highest percentage in this question. It showed that $86.7 \%$ of $100 \%$ of students answered yes that the teacher gave the reading material based on the ability of the students. There is $6.7 \%$ students answered the same result from no and often students' answered. But, there is no one of the students answered sometimes in this question. It proved that percentage of students who gave positive responses about that question was higher than negative responses.

Table 11. Students' Questionnaire Result For Number Eleven

\begin{tabular}{|c|c|c|c|}
\hline Statement of questions & Students Answer & Frequency & Percentage \\
\hline Does the English teacher & Yes & 27 & 90 \\
\hline master all English & No & 1 & 3.3 \\
\hline materials & Sometime & 1 & 3.3 \\
\hline learning process? & Often & 1 & 3.3 \\
\hline
\end{tabular}

From the number eleven questionnaire found that highest answered from the entire question on this questionnaire. It was $90 \%$ of the students answered yes, so it means the students agreed that the teacher mastered all English materials during learning process. On the other hand, all of the percentages of the students answered no, 
Teaching Strategies: EFL Student's Responses Toward Teachers Strategies...

sometime, and often in this questionnaire have the same percentage. Because it was all of the percentage three of them showed the result 3.3\% of the students answered. It concluded that the result have a big positive responses.

Table 12. Students' Questionnaire Result for Number Twelve

\begin{tabular}{lccc}
\hline \multicolumn{1}{c}{ Statement of questions } & Students Answer & Frequency & Percentage \\
\hline Does the English teacher & Yes & 21 & 70 \\
conclude the contents of & No & 1 & 3.3 \\
reading in the last learning & Sometime & 5 & 16.7 \\
section? & Often & 3 & 10 \\
\hline
\end{tabular}

Based on the table above, it showed that $70 \%$ of students answered yes that English teacher concluded the contents of reading in the last of meeting section. On the other hand, the students answered that the teacher only sometimes concluded the contents of reading in the last learning. It was showed by the percentage of the students answered $16.7 \%$. There is also only $10 \%$ of the students answered that the teacher often concluded the content because there are only three students answered often in this questions. Besides, there is only 3,3\% of the students answered no. It can be concluded that the positive responses of the students towards the teacher. Even if there are some of the students gave the different perception of this question.

Table 13. Students' Questionnaire Result for Number Thirteen

\begin{tabular}{|c|c|c|c|}
\hline Statement of questions & Students Answer & Frequency & Percentage \\
\hline Do the students & Yes & 24 & 80 \\
\hline understand the materials & No & 0 & 0 \\
\hline that has given by the & Sometime & 5 & 16.7 \\
\hline English teacher well ? & Often & 1 & 3.3 \\
\hline
\end{tabular}

The finding for the last questionnaire showed that $80 \%$ of the students mentioned yes. It is means they agreed that they understand the materials that has given by the English teacher. Besides $16.7 \%$ of the students answered sometime understand the materials that has given by the English teacher. On the other hand only $3.3 \%$ of the students often understand the material. None of the students answered no toward the understanding of the material that has given by the English teacher.

\section{Discussion}

In this study, the finding of the research can be proved from the researcher's questionnaire to the students at SMA Inshafuddin Banda Aceh. It is the result of the validity of the data and the accordance of research finding. In this discussion described 
all the result of the research that has been found in the students responses about the teacher strategies.

Based on the result of student's response that is got from questionnaire for the first question that is whether the English teacher monitoring reading comprehension of students while the students do not understand about reading text, $73 \%$ most of the students answer yes and there is no one of the students who answer the English teacher does not monitoring reading comprehension of students while the students do not understand about reading text. It means that the teacher gave a positive effect towards the students while the learning process is begun. It was a good percentage because almost perfectly answered by the students that the teacher monitoring the reading comprehension. It was a good result of the students.

The second question is about whether the English teacher asked the students to identify the structure of the story in the reading text. 76.7\% Most of the students gave answer yes and only a few of them gave answer sometime and often. Meanwhile only one student answered that the English teacher does not asked the students to identify the structure of the story in the reading text. The result shown the most of the students gave positive answer, it can be conclude that the English teacher asked the students to identify the structure of the story in the reading text.

Furthermore, the third question is whether the English teacher asked the students to answer questions based on information that the students get from the reading text. $76,7 \%$ of students gave positive answer by answered yes. The students who answer No are two students. It means that they all agree that the English teacher asked the students to answer questions based on information that the students get from the reading text. So, the teacher already provided the text that is related to what the students learned.

The fourth question is whether the English teacher asked the students to make some questions and answer the questions based on reading text. For this question, there are 50\% students who answer yes, and the rest of them answer sometime and often. Furthermore seven students that answered the English teacher did not ask the students to make some questions and answer it based on reading text. It means that only some students argued that the English teacher asked the students to make some questions and answer it based on the text. Half of the students in the classroom agree the teacher asked the students to make questions and answer while teaching reading comprehension. It showed the high percentage that can be assumed as a good role of the teacher. 
Teaching Strategies: EFL Student's Responses Toward Teachers Strategies...

In addition, for the fifth question to find out whether the English teacher asked the students to write the important concept in the reading text. The result shows 50\% students answer yes. Besides, there were eight students answered that the English teacher did not asked them to write the important concept in reading text. The students who answer sometime are four students. Meanwhile, some of them answer often that the English teacher asked the students to write the important concept in the reading text. Then it is a good way of the teacher to asked the students to write important concept because it can make the students memorize the lesson well.

The sixth question is whether the English teacher asked the students to summarize the text by using the original word by the students. The result showed that $43.3 \%$ of the students answer sometime and there is eight students answered yes and no with the same percentage, and also only one of students answered often. It means that the English teacher sometime asked the students to summarize the text by using the original word. It showed that the number of the students said sometimes in high. The teacher actually should ask the students to summarize in their own words because it could make the students learn how to make a sentence in English.

For the seventh question is whether the English teacher asked the students to remember and memorize vocabulary that the students read in the reading text. The students who answered yes is $50 \%$ of the percentage and there is only a few of students answered sometime and often. Five of the students answered that the English teacher did not asked them to remember and memorize vocabulary that the students read in reading text. The teacher actually should asked students to memorize the vocabularies because it can make the students easier to translate the sentences in the future if they remember a lot of vocabularies. It means that only a half of the students that agreed the English teacher asked the students to remember and memorize vocabulary that the students read.

Moreover, the eighth question is about whether the English teacher when the students get bored in teaching learning process, the English teacher gave the students game and motivated the students. 50\% of the students answer yes, and only three of student that answers the teachers does not gave the students motivation. It showed that the English teacher is still lack in motivation and gave game to the students when the students bored in the class.

The ninth question is about whether the English teacher asked the students to point out the main idea of the text that has been read by the students. There were $53.3 \%$ 
students answered yes that the English teacher asked the students to point out the main idea in the text and only two students answered no. It means more than a half of the students in the classroom agree that the teacher did such a way to ask the students in finding the main idea. Only few students that feel the teacher did not asked the students to point out the main idea in a reading text after they read the text. It is the same in the observation that the teacher asked the main ideas of the text.

Moreover, the tenth question about, in the learning activity especially reading showed that $86.7 \%$ of the students said that the English teacher gave the reading material based on the ability of the students. Therefore, only a few of students answered no. It means almost all of the students agreed that the English teacher have a good material that she gave to the students based on the students' ability. It is because the good material that the teacher gave in teaching learning process will obtain the good learning result as well.

Besides, in the eleventh question is about whether the English teacher masters all English materials during the learning process. The researcher found that almost $90 \%$ of the students gave answer yes. There is only one students gave answer no with this question. It can be conclude that the English teacher having the ability in mastering all material in English lesson while teaching and learning process.

Furthermore, for the twelfth question is about whether the English teacher concluded that the contents of reading in the last learning section. The researcher found that $70 \%$ of the students answer yes and for this question, only one student that does not agreed. The students who answer sometime are five students. Meanwhile, the rest of them answered that the English conclude the contents of reading in the last learning section. It means that almost all of the students gave the positive answer by answered yes. It is the important thing for the English teacher to be able to summarize the content of reading to the student. So that the students can be better understand the content of reading.

For the last question is about whether the students understand the materials that has given by the English teacher well. There are $80 \%$ of the students gave positive answer by answered yes, and the students who answer sometime five student and one student answer often. Meanwhile no one of the students answer no. It means that the students understand the material that has given by the English teacher well. It can be concluded that the teacher was good in deliver the lesson towards the student so that is why the students understand well. 
Teaching Strategies: EFL Student's Responses Toward Teachers Strategies...

\section{E. Conclusion}

The researcher conclude that the English teacher of the first grade students in SMA Inshafuddin Banda Aceh based on the students' responses of the teacher strategies in teaching reading comprehension. As in the previous part of the finding and discussion, the researcher concludes that the responses of the student toward to the teacher strategies in teaching reading comprehension it showed positive response. The high percentage shown $90 \%$ of the students said yes that the English teacher masters all materials during learning process. Beside, the positive responses of the students also showed the strategies that the teacher used. There are three strategies that has a high responses those percentage are $73.3 \%$ and $76.7 \%$. Those strategies in the questionnaire are recognizing story structure, question and answer relationship (QARS), monitoring comprehension. It means that the English teacher has good strategies in teaching reading comprehension.

\section{Bibliography}

Alma, B., Mulyadi, H., Razati, G., \& Nuryati, B. L. (2009). Guru Profesional : Menguasai Metode dan Terampil Mengajar. Bandung: Alfabeta.

Cristina. (2019). Mengajar Membaca Itu Mudah. Yogyakarta : CV. Alaf Media.

Margono, S. (2010). Metode Penelitian Pendidikan. Jakarta: Rineka Cipta.

Meliyawati. (2016). Pemahaman Dasar Membaca. Yogyakarta : Deepublish CV Budi Utama.

Mikulecky, B. (2008). Teaching Reading In A Second Language. Pearson Education: Boston University.

Muslaini. (2017). Strategies For Teaching Reading Comprehension. English Education Journal (EEJ), 8(1), 66-77.

Nisa, R., Safura, S., \& Wicoksono, D. F. (2018). Students Ability In Mastering Reading Comprehension. . Vol, 5 No 1. Getsempena English Education Journal (GEEJ), 5(1), 24-30.

Suyanto, \& Jihad, A. (2013). Menjadi Guru Professional. Strategi Meningkatkan Kualifikasi Dan Kualitas Guru Diera Global. Jakarta: Esensi (Erlangga).

Tarigan, H. G., Saifullah, A. R., \& Harnas, K. A. (2011). Membaca Dalam Kehidupan. Bandung: Angkasa. 